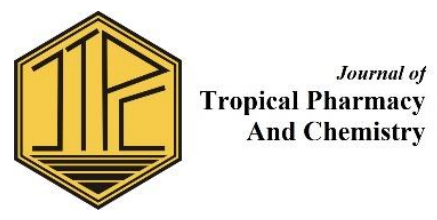

\title{
PHYTOCHEMICAL ASSAY AND ANTIOXIDANT ACTIVITY AGAINST DPPH OF ETHANOL EXTRACT FROM KENAF LEAVES (Hibiscus cannabinus L.)
}

\author{
Rusmini $^{1^{*}}$ Dwinita Aquastini ${ }^{1 *}$, Riama Rita Manullang ${ }^{1}$, Daryono ${ }^{1}$, Ali Sadikin ${ }^{2}$, dan \\ Hadi Kuncoro ${ }^{3}$ \\ ${ }^{1}$ Politeknik Pertanian Negeri Samarinda \\ ${ }^{2}$ Universitas Nahdatul Ulama Samarinda \\ Kampus Gunung Panjang J1.Samratulangi Samarinda 75131 telp.0541-260421/ \\ fax.0541-260680 \\ ${ }^{3}$ Laboratorium Penelitian dan Pengembangan Kefarmasian FARMAKA TROPIS, Fakultas \\ Farmasi Universitas Mulawarman, Samarinda, Kalimantan Timur. \\ *Corresponding Author: mini9964@ rocketmail.com
}

\begin{abstract}
Kenaf (Hibiscus cannabinus L.) is an environmentally friendly natural fiber-producing plant that can produce diversified products, such as paper, wall cover, car interior, geotextile, soil safer, fiber drain, particle board, and plastic reinforcement as well as biofuel industry raw materials. Kenaf plant is a plant that has been only part of the fibers of the stem alone so that many expensive side products such as kenaf leaves after harvesting only as a waste. In Africa, the leaves of kenaf are widely used as medicine. This study aims to analyze phytochemical compounds and known the antioxidant activity from kenaf leaves. Extract from kenaf leaves was assay used phytochemical test and analyzing antioxidant activity with the DPPH method. The results showed the leaves of kenaf contain secondary metabolites of phytochemical compounds such as flavonoids, alkaloids, steroids, saponins, carbohydrates, and tannins and have antioxidant activity with $\mathrm{IC}_{50}$ value $44.48 \mathrm{ppm}$.
\end{abstract}

Keywords: kenaf, flavanoid, tannin, saponin, antioxidants

Submitted on: 11 July 2018

Accepted on: 10 January 2019

DOI: https://doi.org/10.25026/jtpc.v4i5.202

\section{INTRODUCTION}

Some chronic diseases such as cancer, heart, arthritis, diabetes, liver, inflammation and other degenerative diseases are now prevalent in society. Various theories try to explain the causes of degenerative diseases, one of which is the theory of free radicals. Based on this theory, the cause of degenerative diseases is the presence of free radical oxidation processes in biochemical mechanisms occurring in the human body [1].

The process of free radical oxidation can be inhibited with compounds belonging to antioxidants. Antioxidants work by donating their electrons to free 
radical molecules, thereby stabilizing free radicals and stopping chain reactions [2].

Production of free radicals in the body has been balanced by the enzymatic reaction which is a system of defense against free radicals. However, increased production of free radicals due to external factors such as stress, radiation, and pollutants causes the defense system inadequate to protect the body from free radical attack requires additional antioxidants from the outside [3].

Antioxidants from the outside can be obtained in synthetic and natural forms. However, today, synthetic antioxidants are being restricted due to concerns about possible side effects, making natural antioxidants a significant choice in counteracting free radicals [4]. Therefore, efforts to find natural antioxidants from medicinal plants, spices, vegetables, and animals are of concern to current researchers [5].

The kenaf leaves is believed by some African countries as a medicinal plant to relieve pain, appetite enhancers, gout, stomach ache, fever, and worm medicine [6]. The efficacy of the leaves of the kenaf plant as a medicine indicates that containing chemical compounds that have potential pharmacological effects. This study aims to analyze phytochemical compounds and known the antioxidant activity from kenaf leaves.

\section{MATERIAL AND METHODS}

\section{Materials}

Filter paper, ethanol (Merck), iron (III) chloride (Merck), sulfuric acid (Merck), $\mathrm{Mg}$ powders (Brataco), Hydrochloric acid (Merck), Sodium hydroxide (Merck), Dragendorff Reagents, Wagner Reagents, Meyer Reagents, 2\% $\mathrm{AlCl}_{3}$ reagents, Vitamin $\mathrm{C}$ and DPPH reagents. The tool used in this research is a hand sprayer, scales, glassware (Pyrex), blender, sieve 65 mesh, spatula, Rotary
Evaporator (Buchi), desiccator, analytic scales (Ohaus), micropippet, oven, Vortex mixer (Thermo Scientific), drip plate, UVVis spectrophotometer (Dynamica Halo).

\section{Plant Materials}

The main ingredients used in this study are kenaf leaves varieties KR-11 (Hibiscus cannabinus L.)

\section{Phytochemical Test}

Phytochemical testing of the kenaf leaves sample was performed following method procedure [7]. A total of $2 \mathrm{~g}$ of kenaf leaves powder is fed into the test tube, then extracted with $10 \mathrm{~mL}$ of ethanol solvent. After the sample has settled, the sample is filtered by using cotton, and the obtained filtrate is transferred to another test tube for phytochemical testing.

\section{Plant material extraction}

The leaves of kenaf leaves are extracted with ethanol by maceration method for four times, with each time $5 \mathrm{x}$ 24-hour maceration, then applied for two times 24 hours. The maceration results were filtered with a Buchner funnel; the extract was collected and concentrated using $85^{\circ} \mathrm{C}$ rotary evaporator until the ethanol was evaporated and aerated to obtain a viscous extract.

\section{Phenolic identification}

As much as $1 \mathrm{~mL}$ of ethanol extract of kenaf leaves sample was put into the test tube, then added 2 - 3 drops of iron (III) chloride $\left(\mathrm{FeCl}_{3}\right)$ 5\%. The real extract contains phenol when it produces a blackish-blue color.

\section{Alkaloid Identification}

Three test tubes were provided for the ethanol extract of the kenaf leaves a sample of $1 \mathrm{~mL}$ each. After that, each tube was added ten drops of $\mathrm{H}_{2} \mathrm{SO}_{4} 2 \mathrm{~N}$ and shaken vigorously. In the first tube was added Dragendorff reagent, and on the 
second tube added Wagner reagent.. Positive results when the first tube (addition of Dragendorff reagent) produces a red precipitate, and in the second tube (addition of Wagner reagent) yields brownish sediment.

\section{Steroid / Tritepenoid Identification}

The ethanol extract of the kenaf leaves sample was dropped on the drip plate at 3 points (the first point for standard and other points for terpenoid and steroid testing) and allowed to dry. After dry, add two concentrated $\mathrm{H}_{2} \mathrm{SO}_{4}$, then observed the color change. Positive samples when subjected to discoloration to red or brown to terpenoids (triterpenoids) and discoloration to blue, purple, or green for steroids.

\section{Identification of Saponin}

$1 \mathrm{~mL}$ of ethanol extract of kenaf leaves sample was put into the reaction tube, then added $5 \mathrm{~mL}$ hot water and added two drops of $\mathrm{HCl} 2 \mathrm{~N}$ and shaken vigorously. Afterward, it is seen whether the foam forms after being silenced for 10 minutes. Positive samples of saponins are characterized by a lot of froth intensity and consistent for 10 minutes.

\section{Antioxidant assay of leaves kenaf}

The ethanol extract of $70 \%$ of kenaf leaves and vitamin $\mathrm{C}$ was tested for the radical trapping activity against DPPH radical by measuring its absorbance at max after the time obtained at operating time. The solution preparation to be measured was $2.0 \mathrm{ml}$ of DPPH stock solution. The stock solution was placed in $5.0 \mathrm{ml}$ of the flask, then $0.5 \mathrm{ml}$ of the Tris $\mathrm{HCl}$ buffer solution and $0.5 \mathrm{ml}$ of the test compound solution (with different concentrations ) on the extract of kenaf leaves ethanol, and vitamin $\mathrm{C}$, then added ethanol until the sign is then diverted for 2 minutes and silenced during OT (operating time). The stamps used were $0.5 \mathrm{ml}$ of ethanol extract of $70 \%$ of kenaf leaves or vitamin $\mathrm{C}, 0.5 \mathrm{ml}$ of $\mathrm{HCl}$ tris buffer, and ethanol ad $5.0 \mathrm{ml}$. All treatments replicated three times, and replicate measurements three times.

\section{Data Analyze}

Determination of the radical activity of Kenaf leaves. The method used is the DPPH method. The result of DPPH scavenging activity from kenaf leaves extract compared with Vitamin C. Percentage of DPPH radical scavenging activity was calculated by using the following equation.

DPPH scavenging percentage (\%): $\frac{\text { Absorbance Control - Sample Absorbance }}{\text { Absorbance Control }} \times 100 \%$

Moreover, $\mathrm{IC}_{50}$ calculation is a value that describes the amount of fraction concentration from the test extract that can capture free radical by $50 \%$ through linear regression equation expressing the relationship between the concentration of test sample $(\mathrm{X})$ with the average radical catcher activity ( $\mathrm{Y}$ ) of the measurement replication series. The smaller the value of the $\mathrm{IC}_{50}$, the test compound has the effectiveness of a better antioxidant activity.

\section{RESULT AND DISCUSSION}

\section{Phytochemical Test}

Phytochemical tests were performed to determine the active compounds in leaves of kenaf. The results of the phytochemical test of kenaf leaves are listed in Table 1.

The data in Table 1 shows that in the kenaf leaves contained quite a lot of active compounds. Positive kenaf leaves contain flavonoids, alkaloids, steroids, saponins, and tannins. The presence of phytochemical compounds such as flavonoids, tannins indicates that the leaves of kenaf have potential as antioxidants [8]. 
Antioxidant activity assay with DPPH for kenaf leaves ethanol extract was done by using DPPH free radical scavanging method. The antioxidant activity test was performed with ethanol extract in various concentrations $(50,100$, 150, 200 and $250 \mathrm{ppm}$ ) with DPPH reagent and incubated for 30 minutes in the dark room. The color change shows antioxidant activity from purple to yellow. The higher antioxidant activity showed the purple color of DPPH would decrease, causing a decrease in the absorbance of visible light in the spectrophotometer [9].

The percentage of inhibition of each concentration that has been obtained is then made a curve of the regression equation as in figure 1 .

Table 1. The result of Phytochemical Test of kenaf Leaves

\begin{tabular}{ccc}
\hline Secondary metabolites & Test results & Information \\
\hline Flavonoid & + & positive result \\
Alkaloid & + & positive result \\
Steroid & + & positive result \\
Saponin & + & positive result \\
Tannin & + & positive result \\
\hline
\end{tabular}

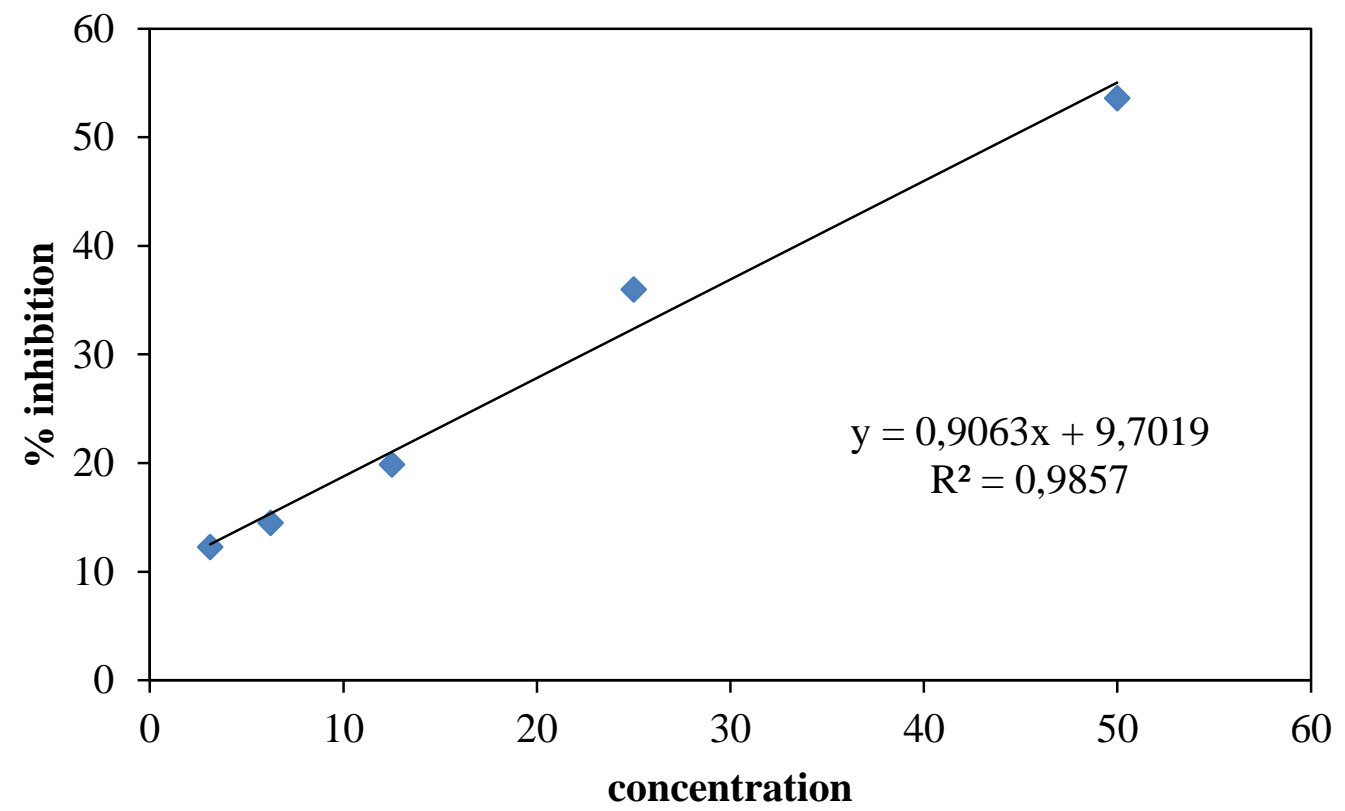

Figure 1. Linear regression equation curve of kenaf leaves ethanol extract

Regression equation in figure 1 is $\mathrm{y}$ $=0.906 \mathrm{x}+9.701$ with value $\mathrm{R} 2$ equal to 0.985 , then used to form $\mathrm{IC}_{50}$ value. From the equation $\mathrm{y}=0.906 \mathrm{x}+9.701$ obtained $\mathrm{IC}_{50}$ value from kenaf leaves ethanol extract of $44,48013 \mathrm{ppm}$. As a comparison used vitamin $\mathrm{C}$ with an $\mathrm{IC}_{50}$ value of 4.48 $\mathrm{ppm}$. The smaller $\mathrm{IC}_{50}$ values indicate that the test compound has a better level of effectiveness as a free radical catcher [10]. When compared with vitamin $\mathrm{C}$, antioxidant activity from the ethanolic 
extract of kenaf leaves is still much weaker. Vitamin $\mathrm{C}$ antioxidant activity is robust because vitamin $\mathrm{C}$ is purely compared with the ethanol extract of leaves of kenaf which still has a lot of phytochemical compounds that may interfere with the antioxidant activity of the leaves of kenaf.

According to [11] a compound has a powerful antioxidant if $\mathrm{IC}_{50}<50 \mathrm{ppm}$, strong if $\mathrm{IC}_{50}$ value is $51-100 \mathrm{ppm}$, while $\mathrm{IC}_{50}$ value is $101-150 \mathrm{ppm}$, and weak if $\mathrm{IC}_{50}$ value is $151-200 \mathrm{ppm}$. According to this classification of ethanol extract of kenaf leaves with an $\mathrm{IC}_{50}$ value of 44.48 $\mu \mathrm{g} / \mathrm{mL}$ has antioxidant activity that is quite good.

According to Rininta [12], plants that have the potential as antioxidants generally contain flavonoid compounds and other secondary metabolite compounds that are rich in antioxidant activity. The results of the experiment of flavonoid content of kenaf leave ethanol extract gave a positive correlation with the antioxidant test result. Where the total content of flavonoids is high enough to have enough good antioxidant activity as well, this is due to the presence of free hydroxyl $(-\mathrm{OH})$ functional groups and the conjugated double bonds that are attached to the flavonoids that may act as antioxidants [13].

\section{CONCLUSION}

Based on the research that has been done, it can be concluded that kenaf chemical leaves extract contains some phytochemical compounds such as flavonoids, alkaloids, steroids, saponins, carbohydrates and tannins and has a reason for antioxidant activity against DPPH with an $\mathrm{IC}_{50}$ value of $44.48 \mu \mathrm{g} / \mathrm{mL}$.

\section{ACKNOWLEDGMENTS}

Authors wish to thank the Ministry of Research, Technology, and Higher Education for providing the Competitive Research Grants 2017 and 2018 no.
05/PL..21.C/PL/2018 that funded this study. Authors also thank Head of P2M Unit, State Agricultural Polytechnic Institute of Samarinda and all parties that helped the completion of this research.

\section{REFERENCES}

[1]. Oeinitan, J. 2013. Antioxidant Power of Ethanol Extract of Mangosteen Fruit (Garcinia mangostana Linn.) Result Stirring And Reflux. Jurnal Ilmiah Mahasiswa Surabaya. 1 (2): 1-2.

[2]. Sies, H. 1997. Oxidative Stress: Oxidants and Antioxidants. Experimental Physiology. 82: 291295.

[3]. Soares, J.R., Dinis, T. C. P., Cunha, A. P., Almeida, L. M. 1997. Antioxidant Activities of Some Extracts of Thymus zigis. Free Radical Biology and Medicine. 26: 468-478.

[4]. Sunarni, T., Pramono, S., \& Asmah, R. 2007. Flavonoids Antioxidants are radical catchers of Kepel leaves (Stelechocarpus burahol (B1.) Hook f. \& Th.). Pharmaceutical Magazine Indonesia. 18 (3): 111-116.

[5]. Silalahi, R. M. 2010. Characterization of Simplicia, Phytochemical Screening and Antioxidant Activity Test of Ethanol Extract Leaves of Broccoli Fruit Flower Fraction (Brassicaoleracea L. var. Botrytis L.) [Thesis]. FMIPA Universitas Sumatera Utara, Medan.

[6]. Nurnasari, E. 2017. Use of Kenaf leaves and Seed for Health. WARTA [Research and development of Tanaman Industri, VOl. 23. No.I. Agricultural Research and Development Center. Center for Plantation Research and Development. Bogor. 
[7]. Harbone, J. B., 1996. Phytochemical Method: Guide of Modern Way to Analyze Plants, Second Issue. Institut Teknologi Bandung, Bandung.

[8]. Pratt, D.E. (1992). Natural Antioxidants from Plant material. In Phenolic Compounds in Food and their Effects on Health (Vol II). Antioxidants and Cancer Prevention; Huang, M-T., Ho, C- T., Lee, C., Eds : ACS Symposium Series 507; American Chemical Society, Washington DC.

[9]. Molyneux, P. 2004. The Use of the Stable Free Radical diphenylpicrylhydrazyl (DPPH) for Estimating Antioxidant Activity. Journal of Science of Technology. 26 (2): 211-219.
[10]. Cheng Y. and Prusoff W.H., 1973, Relationship Between the Inhibition Constant and the Concentration of Inhibition Which Causes 50 percent Inhibition (IC50) of An 60nzymatic Reaction. Biochemical Pharmacology. 22(23): 3099-3108.

[11]. Blois, MS. 2005. Antioxidant determination by the use of stable free radical. Nature. 181: 11911200.

[12]. Rininta, N. 2008. KLT AutographyCUPRAC as a Quick Detection Technique Antioxidant Compound. [Essay]. FMIPA IPB, Bogor.

[13]. Parwata, I.M.O.A., Wiwik, S.R., and Raditya, Y. 2009. Isolation and Antiradical Test of Free Essential Oil in Betel Leaves (Piper betle L.) by Ultraviolet Spectroscopy Appear. Journal of Chemistry. 3 (1): 7. 